\title{
Struktur Komunitas Mesofauna Tanah dan Kapasitas Infiltrasi Air setelah diberi Perlakuan Biostarter Pengurai Bahan Organik
}

\author{
Latifah Fitria Andriani, Rully Rahadian dan Mochammad Hadi \\ Laboratorium Ekologi dan Biosistematika Jurusan Biologi FSM Undip \\ Email : latifafitria@gmail.com
}

\begin{abstract}
Research about the biostarter application on the biopori concept through parameter of soil mesofauna community structure and water infiltration capacity was aimed to investigate the effect of biostarter product on soil mesofauna community structure and water infiltration rate at Lubang Resapan Biopori (LRB) aged 30 days and 50 days, also the correlation between mesofauna community structure and soil infiltration capacity. This study uses a single factor completely randomized design, which has 5 treatments including control, EM4, Bioklin, Mig Dec, and Orgadec. The results showed that the addition of biostarter affects soil mesofauna community structure, particularly positive effect on the abundance of Oribatida and Mesostigmata. Products Orgadec was able to increase faster the abundance of mesofauna both at the age of LRB 30 days and 50 days, whereas Mig Dec and EM4 starting to show its influence on the LRB after 50 days. Infiltration rate LRB age of 30 days showed a significant difference in treatment of Orgadec only, whereas at the age of 50 days, the significant difference is indicated in the treatment EM4 , Mig Dec and Orgadec. Based on the Spearman correlation test, the total number of individuals and number of Oribatida. Both showed significant positive correlation with the infiltration rate.
\end{abstract}

Keywords: biostarter, community structure, soil mesofauna, infiltration rate, $L R$

\begin{abstract}
Abstrak
Penelitian mengenai aplikasi biostarter terhadap konsep biopori melalui parameter struktur komunitas mesofauna tanah dan kapasitas infiltrasi air ini bertujuan untuk mengetahui pengaruh produk biostarter terhadap struktur komunitas mesofauna tanah dan laju infiltrasi air pada Lubang Resapan Biopori (LRB) umur 30 hari dan 50 hari, serta korelasi antara struktur komunitas mesofauna tanah dengan kapasitas infiltrasi. Penelitian ini menggunakan Rancangan Acak Lengkap faktor tunggal, yaitu penambahan EM4, Bioklin, Mig Dec, dan Orgadec. Hasil penelitian menunjukkan bahwa penambahan biostarter memengaruhi struktur komunitas mesofauna tanah, khususnya berpengaruh positif terhadap kelimpahan Oribatida dan Mesostigmata. Produk Orgadec mampu bekerja lebih cepat dalam meningkatkan kelimpahan individu baik pada umur LRB 30 hari maupun 50 hari, sedangkan EM4 dan Mig Dec mulai menunjukkan pengaruhnya terhadap kelimpahan setelah umur LRB 50 hari. Laju infiltrasi LRB umur 30 hari menunjukkan adanya perbedaan yang nyata pada perlakuan Orgadec saja, sedangkan pada umur 50 hari, perbedaan secara nyata ditunjukkan pada perlakuan EM4, Mig Dec dan Orgadec. Berdasarkan uji korelasi Spearman, adanya korelasi positif antara jumlah total individu dan jumlah Oribatida menunjukkan perbedaan yang nyata dengan laju infiltrasi.
\end{abstract}

Kata kunci: biostarter, struktur komunitas, mesofauna tanah, laju infiltrasi, LRB

\section{PENDAHULUAN}

Peningkatan jumlah penduduk berpengaruh terhadap perubahan tata guna lahan. Bertambahnya penduduk yang tidak diikuti dengan penambahan lahan sebagai tempat tinggal mendorong terjadinya alih fungsi Ruang Terbuka Hijau (RTH) untuk kepentingan tersebut. Berkurangnya RTH menyebabkan lahan-lahan resapan air menjadi terbatas karena dimanfaatkan untuk daerah permukiman dan perekonomian. Berkurangnya lahan resapan air, berdampak buruk bagi lingkungan, seperti timbulnya banjir dan kekeringan. Untuk mengatasi masalah banjir dan kekeringan ini, diperlukan upaya untuk mengoptimalkan daya resap air hujan pada suatu 
lahan terutama untuk lahan-lahan seperti tanah permukiman, pusat perbelanjaan, dan sebagainya.

Salah satu upaya meningkatkan daya resap air (infiltrasi) yaitu dengan mengaplikasikan konsep biopori tanah melalui pembuatan LRB (Lubang Resapan Biopori). Wuest (2001) menyatakan bahwa konsep biopori tanah itu sendiri merupakan pori yang terbentuk secara alami di dalam tanah akibat berbagai aktivitas organisme di dalamnya seperti jamur, bakteri dan fauna tanah (makrofauna, mesofauna, dan mikrofauna). Adanya fauna tanah memberikan pengaruh terhadap banyaknya pori tanah yang terbentuk, sehingga dapat meningkatkan aerasi, drainase dan infiltrasi ke dalam tanah. Menurut Swift et al. (1979 in Rahadian, 2009), walaupun mesofauna tanah memiliki peranan yang sama dengan makrofauna tanah dalam menfragmentasi bahan organik, akan tetapi mesofauna memiliki peran lebih dalam meregulasi populasi mikroorganisme tanah khususnya jamur, dibandingkan makrofauna seperti Amphipoda, Isopoda, cacing dan Molluska. Kelimpahan dan keanekaragaman mesofauna tanah juga umumnya lebih tinggi dibandingkan dengan makrofauna tanah (Hopkin, 2002 in Rahadian, 2009 ).

Salah satu faktor yang memengaruhi struktur komunitas mesofauna tanah adalah ketersediaan nutrisi. Nutrisi tersebut dapat berupa serasah, material kayu, spora jamur, miselia jamur, bakteri, dan lain sebagainya. Scheu \& Folger (2004) mengemukakan bahwa beberapa kelompok taksa mesofauna tanah yang berpotensi sebagai pembentuk biopori, lebih menyukai miseliamiselia jamur (kapang) sebagai salah satu nutriennya. Jamur dan bakteri yang ditemukan di dalam saluran pencernaan beberapa mesofauna ini, berasosiasi dengan bahan organik sebagai substrat tumbuh yang kemudian dicerna bersama oleh mesofauna tanah.

Kemampuan jamur dan bakteri dalam menguraikan senyawa organik, mendorong berbagai industri pertanian memanfaatkan biodiversitas mikroba di alam sebagai suatu produk biostarter yang dapat bernilai komersial. Pemanfaatan produk biostarter komersial ini diharapkan dapat berpengaruh positif terhadap struktur komunitas mesofauna tanah di dalam LRB yang secara tidak langsung dapat meningkatkan kapasitas infiltrasi.

\section{BAHAN DAN METODE}

Peningkatan jumlah penduduk berpengaruh terhadap perubahan tata guna lahan. Bertambahnya penduduk yang tidak diikuti dengan penambahan lahan sebagai tempat tinggal mendorong terjadinya alih fungsi Ruang Terbuka Hijau (RTH) untuk kepentingan tersebut. Berkurangnya RTH menyebabkan lahan-lahan resapan air menjadi terbatas karena dimanfaatkan untuk daerah permukiman dan perekonomian. Berkurangnya lahan resapan air, berdampak buruk bagi lingkungan, seperti timbulnya banjir dan kekeringan. Untuk mengatasi masalah banjir dan kekeringan ini, diperlukan upaya untuk mengoptimalkan daya resap air hujan pada suatu lahan terutama untuk lahan-lahan seperti tanah permukiman, pusat perbelanjaan, dan sebagainya.

Salah satu upaya meningkatkan daya resap air (infiltrasi) yaitu dengan mengaplikasikan konsep biopori tanah melalui pembuatan LRB (Lubang Resapan Biopori). Wuest (2001) menyatakan bahwa konsep biopori tanah itu sendiri merupakan pori yang terbentuk secara alami di dalam tanah akibat berbagai aktivitas organisme di dalamnya seperti jamur, bakteri dan fauna tanah (makrofauna, mesofauna, dan mikrofauna). Adanya fauna tanah memberikan pengaruh terhadap banyaknya pori tanah yang terbentuk, sehingga dapat meningkatkan aerasi, drainase dan infiltrasi ke dalam tanah. Menurut Swift et al. (1979 in Rahadian, 2009), walaupun mesofauna tanah memiliki peranan yang sama dengan makrofauna tanah dalam menfragmentasi bahan organik, akan tetapi mesofauna memiliki peran lebih dalam meregulasi populasi mikroorganisme tanah khususnya jamur, dibandingkan makrofauna seperti Amphipoda, Isopoda, cacing dan Molluska. Kelimpahan dan keanekaragaman mesofauna tanah juga umumnya lebih tinggi dibandingkan dengan makrofauna tanah (Hopkin, 2002 in Rahadian, 2009 ).

Salah satu faktor yang memengaruhi struktur komunitas mesofauna tanah adalah ketersediaan nutrisi. Nutrisi tersebut dapat berupa serasah, material kayu, spora jamur, miselia jamur, bakteri, dan lain sebagainya. Scheu \& Folger 
(2004) mengemukakan bahwa beberapa kelompok taksa mesofauna tanah yang berpotensi sebagai pembentuk biopori, lebih menyukai miseliamiselia jamur (kapang) sebagai salah satu nutriennya. Jamur dan bakteri yang ditemukan di dalam saluran pencernaan beberapa mesofauna ini, berasosiasi dengan bahan organik sebagai substrat tumbuh yang kemudian dicerna bersama oleh mesofauna tanah.

Kemampuan jamur dan bakteri dalam menguraikan senyawa organik, mendorong berbagai industri pertanian memanfaatkan biodiversitas mikroba di alam sebagai suatu produk biostarter yang dapat bernilai komersial. Pemanfaatan produk biostarter komersial ini diharapkan dapat berpengaruh positif terhadap struktur komunitas mesofauna tanah di dalam LRB yang secara tidak langsung dapat meningkatkan kapasitas infiltrasi

\section{HASIL DAN PEMBAHASAN}

1. Struktur Komunitas Mesofauna Tanah

Penambahan biostarter pada LRB umur 30 hari belum terlihat pengaruhnya dalam meningkatkan jumlah individu mesofauna tanah, kecuali padaOrgadec. Kemudian setelah umur LRB 50 hari, penambahan biostarter jenis EM4 dan Mig Dec mulai terlihat pengaruhnya sama seperti Orgadec dalam meningkatkan jumlah individu mesofauna tanah.

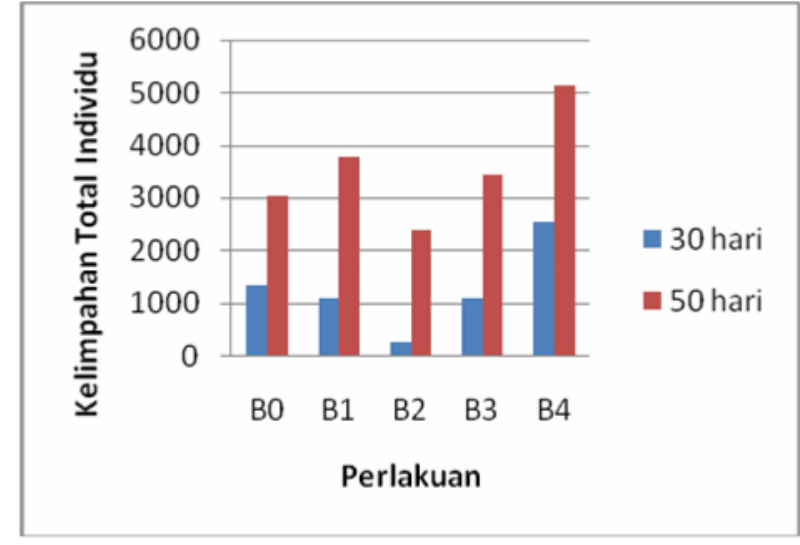

Gambar 1. Kelimpahan Total Individu. B0, Kontrol; B1, EM4; B2, Bioklin; B3, Mig Dec; B4, Orgadec

Berkaitan dengan komposisi dalam biostarter, Orgadec tersusun atas jamur Trichoderma pseudokoningii dan bakteri Cytophaga spp, yang diduga lebih disukai langsung oleh taksa mesofauna tanah terutama taksa-taksa tertentu yang sangat mendominasi di LRB baik pada 30 hari maupun 50 hari. Untuk produk EM4 dan Mig Dec cenderung mulai disukai mesofauna tanah pada saat LRB mencapai umur 50 hari sehingga kelimpahan total individu mulai terlihat meningkat di umur 50 hari, sedangkan penambahan Bioklin baik di LRB umur 30 hari maupun 50 hari tidak menunjukkan pengaruh terhadap kelimpahan individu, cenderung menurunkan kelimpahan individu mesofauna tanah. Hal ini diduga komposisi nutrisi yang terkandung di dalam Bioklin tidak disukai mesofauna tanah.

Tabel 1. Jumlah Individu (n) dan Kelimpahan relatif (Di \%) Mesofauna tanah yang ditemukan pada umur LRB 30 hari

\begin{tabular}{|c|c|c|c|c|c|c|c|c|c|c|c|}
\hline \multirow{3}{*}{ No } & \multirow{3}{*}{ Taksa } & \multicolumn{10}{|c|}{ Jumlah Individu dan Kelimpahan Relatif pada Umur LRB 30 hari } \\
\hline & & \multicolumn{2}{|c|}{ B0 } & \multicolumn{2}{|c|}{$\mathrm{B} 1$} & \multicolumn{2}{|c|}{ B2 } & \multicolumn{2}{|c|}{ B3 } & \multicolumn{2}{|c|}{ B4 } \\
\hline & & $\mathrm{n}$ & Di & $\mathrm{n}$ & Di & $\mathrm{n}$ & Di & $\mathrm{n}$ & Di & $\mathrm{n}$ & $\mathrm{Di}$ \\
\hline 1 & Oribatida & 323 & $24,24^{*}$ & 950 & $87,83^{*}$ & 192 & $75,12^{*}$ & 993 & $91,57^{*}$ & 2301 & $91,16^{*}$ \\
\hline 2 & Mesostigmata & 910 & $68,39^{*}$ & 45 & 4,13 & 19 & 7,28 & 40 & 3,69 & 78 & 3,08 \\
\hline 3 & Formicidae & 72 & 5,43 & 9 & 0,88 & 34 & $13,27^{*}$ & 21 & 1,94 & 100 & 3,99 \\
\hline 4 & Prostigmata & - & - & 17 & 1,60 & 1 & 0,51 & 16 & 1,45 & 27 & 1,06 \\
\hline 5 & Entomobrydae & 20 & 1,53 & 10 & 0,92 & 3 & 1,16 & 3 & 0,31 & 10 & 0,31 \\
\hline 6 & Psocoptera & 1 & 0,05 & 22 & 2,00 & 1 & 0,58 & 4 & 0,40 & 2 & 0,10 \\
\hline 7 & Staphylinidae & - & - & 19 & 1,76 & - & - & - & - & - & - \\
\hline 8 & Insecta (larva) & - & - & 7 & 0,59 & 3 & 1,14 & 3 & 0,31 & 3 & 0,12 \\
\hline
\end{tabular}




\begin{tabular}{llrrrrrrrrrr}
9 & Arachnae & 5 & 0,35 & 3 & 0,28 & 2 & 0,77 & 2 & 0,18 & 2 & 0,09 \\
10 & Isotomidae & - & - & - & - & - & - & 2 & 0,40 & - & - \\
11 & Isopoda & - & - & - & - & - & - & - & - & 1 & 0,03 \\
12 & Ceratopogonidae & - & - & - & - & 1 & 0,16 & - & - & - & - \\
\hline & Jumlah & $\mathbf{1 3 3 1}$ & 100 & $\mathbf{1 0 8 2}$ & 100 & $\mathbf{2 5 6}$ & 100 & $\mathbf{1 0 8 4}$ & 100 & $\mathbf{2 5 2 4}$ & 100 \\
\hline
\end{tabular}

Keterangan : B0= Kontrol, B1 = EM4, B2 = Bioklin, B3 = Migdec, dan B4 = Orgadec

$*$ = taksa dominan (Di $>10 \%)$

Tabel 2. Jumlah Individu (n) dan Kelimpahan relatif (Di \%) Mesofauna tanah yang ditemukan pada umur LBR 50 Hari

\begin{tabular}{|c|c|c|c|c|c|c|c|c|c|c|c|}
\hline \multirow{3}{*}{ No } & \multirow{3}{*}{ Taksa } & \multicolumn{10}{|c|}{ Jumlah Individu dan Kelimpahan Relatif pada Umur LRB 50 hari } \\
\hline & & \multicolumn{2}{|c|}{ B0 } & \multicolumn{2}{|c|}{ B1 } & \multicolumn{2}{|c|}{$\mathrm{B} 2$} & \multicolumn{2}{|c|}{ B3 } & \multicolumn{2}{|c|}{$\mathrm{B} 4$} \\
\hline & & $\mathrm{n}$ & Di & $\mathrm{n}$ & Di & $\mathrm{n}$ & Di & $\mathrm{n}$ & Di & $\mathrm{n}$ & Di \\
\hline 1 & Oribatida & 1597 & $52,53^{*}$ & 2923 & $77,51^{*}$ & 2012 & $84,64^{*}$ & 2536 & $73,68^{*}$ & 4155 & $80,70^{*}$ \\
\hline 2 & Mesostigmata & 1247 & $41,02^{*}$ & 723 & $19,17^{*}$ & 289 & $12,16^{*}$ & 630 & $18,30^{*}$ & 782 & $15,19^{*}$ \\
\hline 3 & Formicidae & 133 & 4,38 & 31 & 0,82 & 42 & 1,77 & 165 & 4,79 & 137 & 2,66 \\
\hline 4 & Prostigmata & 14 & 0,46 & 20 & 0,53 & 1 & 0,04 & 20 & 0,58 & 27 & 0,52 \\
\hline 5 & Entomobrydae & 33 & 1,09 & 17 & 0,45 & 17 & 0,72 & 59 & 1,71 & 32 & 0,62 \\
\hline 6 & Psocoptera & 3 & 0,07 & 24 & 0,64 & 3 & 0,13 & 4 & 0,12 & 2 & 0,04 \\
\hline 7 & Staphylinidae & - & - & 19 & 0,50 & - & - & - & - & 2 & 0,04 \\
\hline 8 & Insecta (larva) & 3 & 0,11 & 8 & 0,21 & 7 & 0,29 & 10 & 0,29 & 6 & 0,12 \\
\hline 9 & Arachnae & 9 & 0,30 & 5 & 0,13 & 4 & 0,17 & 7 & 0,20 & 5 & 0,10 \\
\hline 10 & Isotomidae & 1 & 0,03 & - & - & - & - & 10 & 0,29 & - & - \\
\hline 11 & Isopoda & 1 & 0,03 & 1 & 0,03 & 2 & 0,08 & 1 & 0,03 & 1 & 0,02 \\
\hline 12 & Ceratopogonidae & - & - & - & - & 1 & 0,04 & - & - & - & - \\
\hline & Jumlah & 3041 & 100 & 3771 & 100 & 2378 & 100 & 3442 & 100 & 5146 & 100 \\
\hline
\end{tabular}

Keterangan : B0= Kontrol, B1 = EM4, B2 = Bioklin, B3 = Migdec, dan B4 = Orgadec

$*$ = taksa dominan $(\mathrm{Di}>10 \%)$

Berdasarkan taksa yang mendominasi di LRB baik di 30 hari maupun 50 hari, Oribatida mendominasi di semua perlakuan, tetapi secara umum penambahan biostarter cenderung meningkatkan populasinya kecuali pada Bioklin. Hal ini sesuai pernyataan Schneider (2005), berdasarkan kebiasaan makannya, Oribatida merupakan salah satu kelompok Acari yang menyukai mikroorganisme terutama jamur dan bakteri, serta sisa / residu tanaman. Kemudian pada umur LRB 50 hari, penambahan biostarter mampu meningkatkan populasi Mesostigmata sehingga menjadi taksa yang dominan bersama dengan Oribatida. Peningkatan populasi Mesostigmata di LRB umur 50 hari mampu menekan populasi taksa lain yang sebelumnya menjadi dominan di LRB umur 30 hari seperti Formicidae pada perlakuan Bioklin. Hal itu menunjukkan bahwa adanya suatu interaksi seperti kompetisi, predasi dan sebagainya di dalam LRB, sesuai yang dinyatakan oleh Brussaard et al.
(2006), siklus nutrisi yang terjadi di dalam tanah memunculkan suatu interaksi antar organisme tanah baik itu makro maupun mikroorganisme

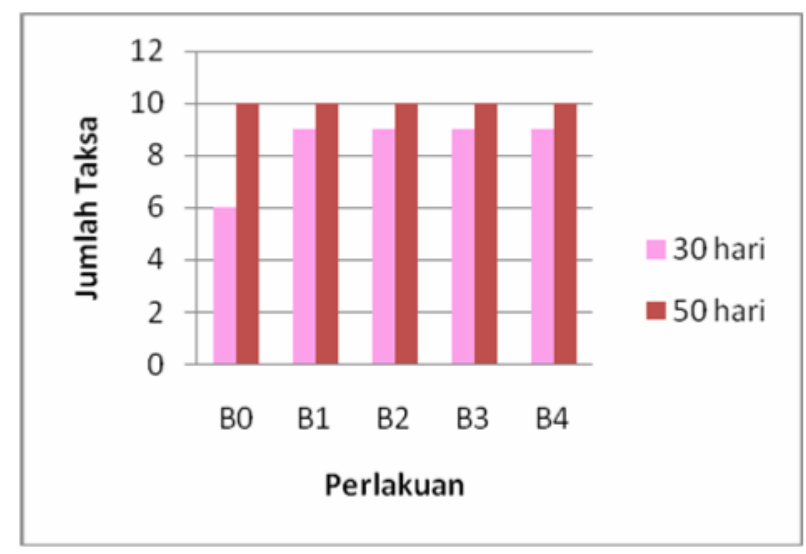

Gambar 2. Jumlah Taksa. B0, Kontrol; B1, EM4; B2, Bioklin; B3, Mig Dec; B4, Orgadec 
Jenis biostarter tidak memengaruhi jumlah taksa yang ditemukan di LRB. Tetapi apabila dikaitkan dengan hipotesis, hal ini sesuai dengan dugaan bahwa penambahan biostarter mampu meningkatkan kehadiran taksa mesofauna tanah, dapat terlihat di LRB umur 30 hari bahwa penambahan biostarter mampu meningkatkan jumlah taksa yang ditemukan

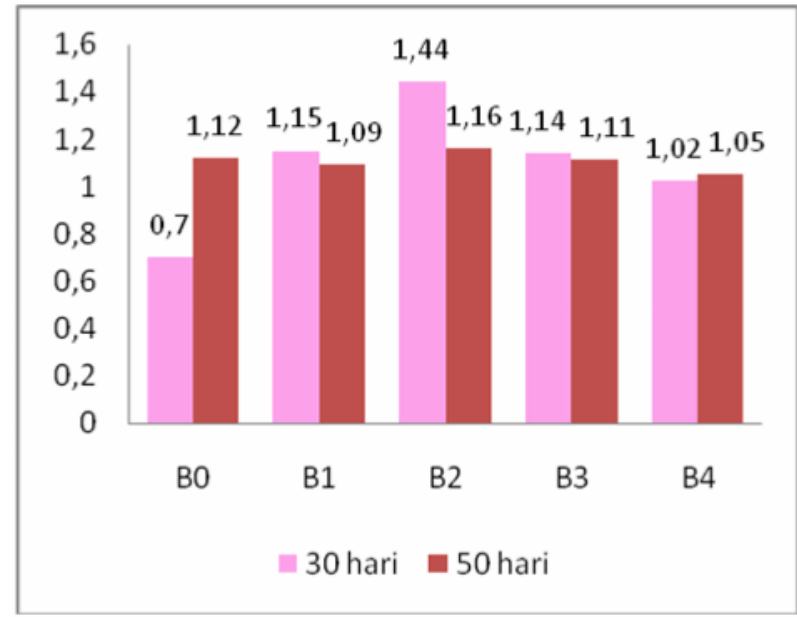

Gambar 3. Indeks Kekayaan Taksa. B0, Kontrol; B1, EM4; B2, Bioklin; B3, Mig Dec; B4, Orgadec

Penambahan biostarter mampu meningkatkan kekayaan taksa di 30 hari. Kemudian pada LRB mencapai umur 50 hari, menunjukkan bahwa adanya penambahan biostarter tidak berpengaruh pada kekayaan taksa karena nilai indeksnya cenderung sama. Hal ini menunjukkan bahwa pemberian bahan organik sebagai nutrisi yaitu berupa jerami saja sudah mampu menarik kehadiran taksa mesofauna tanah pada LRB. Sedangkan penambahan biostarter berperan dalam meningkatkan jumlah individu mesofauna tanah di dalam LRB umur 50 hari.

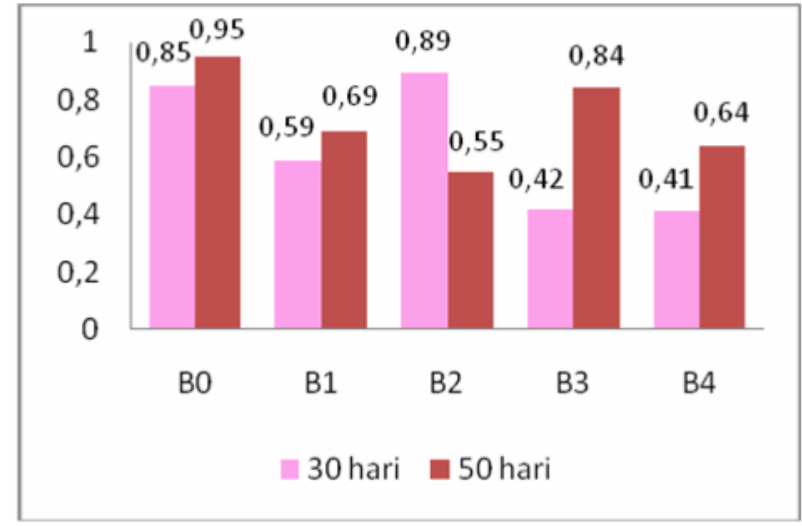

Gambar 4. Indeks Keanekaragaman. B0, Kontrol; B1, EM4; B2, Bioklin; B3, Mig Dec; B4, Orgadec

Penambahan biostarter cenderung menurunkan keanekaragaman mesofauna tanah, kecuali pada Bioklin. Penurunan keanekaragaman membuktikan bahwa penambahan biostarter memengaruhi kestabilan ekosistem yang ada di dalam LRB. Setelah mencapai umur 50 hari, adanya penambahan biostarter tidak memengaruhi keanekaragaman. Jumlah taksa dominan yang lebih tinggi pada perlakuan kontrol dan Bioklin, menunjukkan bahwa pada komunitas tersebut tidak dijumpai kelompok taksa yang terlalu dominan.

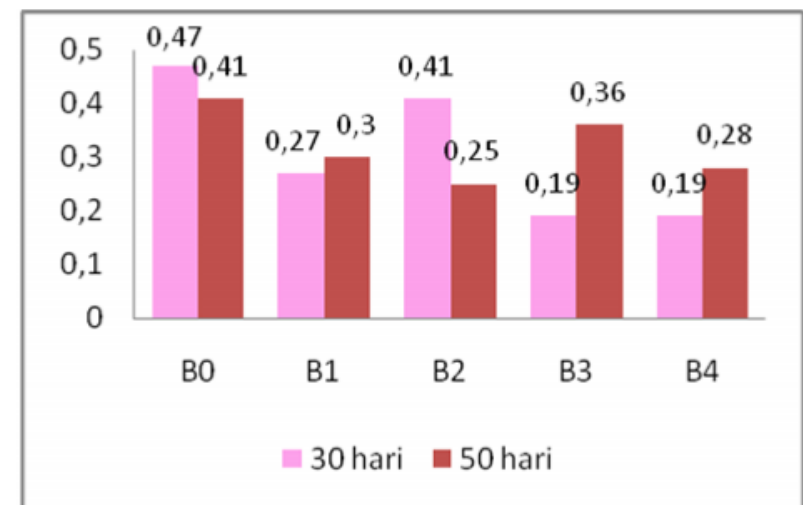

Gambar 5. Indeks Perataan Taksa. B0, Kontrol; B1, EM4; B2, Bioklin; B3, Mig Dec; B4, Orgadec

Penambahan biostarter cenderung menurunkan perataan taksa baik di umur 30 hari 
maupun 50 hari. Hal itu sesuai dengan kelimpahan baik di 30 hari maupun di 50 hari bahwa adanya taksa yg sangat dominan menekan persebaran taksa lain. Magurran (1988) menyatakan bahwa nilai perataan akan cenderung tinggi bila komunitas tersebut tidak didominasi oleh satu spesies saja.

Selain memengaruhi keanekaragaman mesofauna tanah, penambahan biostarter bersamasama dengan jerami sebagai bahan organik tambahan pada lubang resapan juga terbukti memengaruhi sifat fisik dan kimia tanah. Perubahan sifat fisik pada tanah dapat dilihat pada hasil grain size test yang dilakukan di Laboratorium Mekanika Tanah jurusan Teknik Sipil Undip.

Tabel 3 Komposisi Tekstur Tanah Sebelum dan Sesudah Perlakuan (\%)

\begin{tabular}{lcc}
\hline Komposisi & $\begin{array}{c}\text { Sebelum } \\
\text { Perlakuan } \\
(0 \text { hari) }\end{array}$ & $\begin{array}{c}\text { Setelah } \\
\text { perlakuan } \\
(50 \text { hari })\end{array}$ \\
\hline Pasir (Sand) & 19,99 & 26,78 \\
Lempung & 25,90 & 26,67 \\
$\begin{array}{l}\text { Clay) } \\
\text { Debu (Silt) }\end{array}$ & 54,11 & \\
\hline
\end{tabular}

Persentase komposisi tektur tanah sebelum dan setelah perlakuan penambahan biostarter mengalami peningkatan pada komposisi pasir dan lempung serta penurunan pada komposisi debu. Peningkatan komposisi pasir dan lempung sesuai dengan salah satu fungsi biostarter bahan organik, yaitu untuk memperbaiki sifat fisik tanah melalui proses dekomposisi bahan organik. Menurut Hanafiah (2005), banyak faktor yang memengaruhi tekstur tanah, diantaranya adalah sumber bahan organik, pembentukan humus, sifat fisika-kimia tanah, peredaran unsur hara, perkembangan struktur tanah, dekomposisi bahan organik dan lain sebagainya. Selain itu, fauna tanah juga merupakan salah satu faktor yang memengaruhi dan dapat dipengaruhi oleh tekstur tanah. Darmawidjaya (1990) menyatakan bahwa perbedaan dan perubahan tekstur tanah, dapat memengaruhi jumlah populasi dan keragaman organisme tanah baik makro maupun mikroorganisme.
Perubahan kimiawi tanah dapat dilihat berdasarkan hasil uji kandungan bahan organik yang dilakukan pada sampel dengan dan tanpa perlakuan (bahan organik tambahan dan biostarter).

Tabel 4 Kandungan Bahan Organik Sebelum dan Sesudah Perlakuan (\%)

\begin{tabular}{ccc}
\hline Ulangan & $\begin{array}{c}\text { Sebelum Perlakuan } \\
(0 \text { hari })\end{array}$ & $\begin{array}{c}\text { Setelah Perlakuan } \\
(50 \text { hari })\end{array}$ \\
\hline 1 & 11,20 & 29,88 \\
2 & 11,76 & 28,04 \\
3 & 14,34 & 27,61 \\
\hline Rata-rata & 12,43 & 28,51 \\
\hline
\end{tabular}

Berdasarkan hasil uji kandungan bahan organik, persentase kandungan bahan organik mengalami peningkatan setelah diberi penambahan biostarter. Hal itu menunjukkan bahwa pemberian biostarter dalam tanah mampu meningkatkan kualitas substrat organik dalam LRB sebagai nutrisi untuk mesofauna tanah didalamnya, sehingga faeces yang dihasilkan oleh mesofauna tanah mampu menambah kandungan bahan organik tanah. Brussaard et al. (2006) menyatakan bahwa faeces yang dihasilkan oleh fauna tanah mampu menambah kandungan bahan organik tanah karena substrat organik yang terfragmentasi oleh mesofauna tanah dan terdekomposisi dengan bantuan mikroorganisme, dicerna oleh mesofauna sehingga faeces yang dihasilkan memiliki kandungan bahan organik lebih tinggi dibandingkan material organik sebelum terdekomposisi. 
2. Kapasitas Infiltrasi

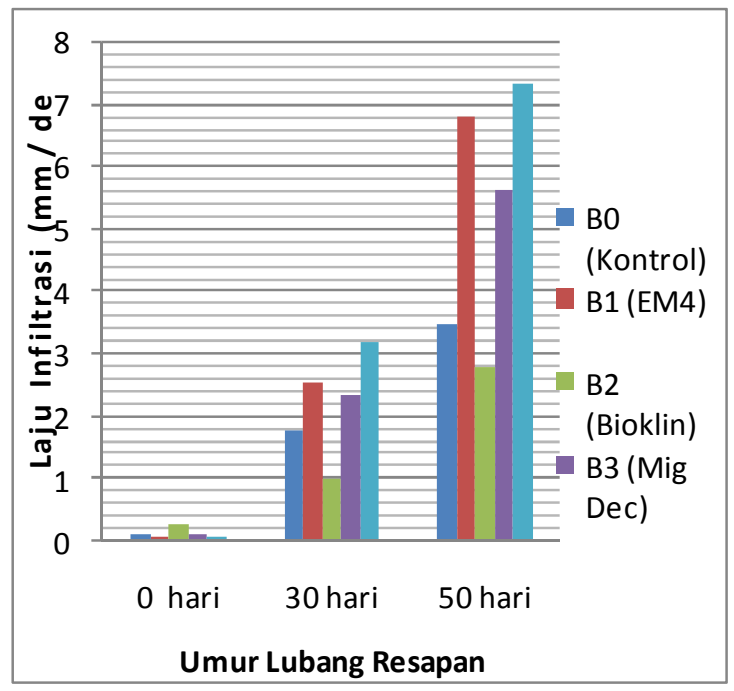

Gambar 6. Laju Infiltrasi 0 hari, 30 hari dan 50 hari

Peningkatan laju infiltrasi pada lahan setelah diberi tambahan bahan organik menunjukkan bahwa pemberian bahan organik tanah memengaruhi sifat fisik, kimia dan biologi tanah. Pengaruh bahan organik secara biologi adalah dengan menjadi sumber nutrisi bagi mikroorganisme tanah seperti jamur, bakteri dan mikroorganisme lainnya serta organisme tanah lain khususnya mesofauna tanah. Pengaruh pemberian bahan organik bagi sifat fisik tanah menurut Hadisuwito (2007), ditunjukkan dengan kemampuannya dalam merangsang granulasi, menurunkan plastisitas dan kohesi, serta meningkatkan kemampuan tanah untuk menahan dan mendistribusikan air dan udara di dalam tanah. Hal ini dikarenakan penggunaan bahan organik akan berpengaruh terhadap tekstur dan kadar liat tanah dalam mengikat air. Secara kimiawi, pemberian bahan organik berupa jerami menurut Yulipriyanto (2010), dapat meningkatkan ketersediaan unsur hara, kapasitas tukar kation dan proses pelapukan bahan mineral. Pengaruh secara kimiawi ini dapat dilihat pada Tabel 4.5 yaitu adanya peningkatan kandungan bahan organik pada sampel tanah sebelum dan sesudah diberi perlakuan penambahan bahan organik tanah dan biostarter.

Perlakuan penambahan biostarter pada jerami padi sebagai substrat bahan organik tanah juga memainkan peranan penting disamping peran bahan organik di dalam tanah. Produk biostarter yang dijual secara komersial di pasaran seperti EM4, Bioklin, Mig Dec dan Orgadec, memiliki kandungan makro dan mikronutrien serta komposisi starter mikroorganisme tertentu yang berbeda antara produk satu dan yang lainnya. Menurut Sutanto (2002), salah satu peranan umum mikroorganisme dalam biostarter adalah untuk menstabilkan kondisi kimia dan fisika tanah, sehingga secara keseluruhan merupakan soil conditioner. Tujuan utama penambahan biostarter pada lubang resapan biopori disamping peranan mikroorganismenya secara umum adalah untuk menambah populasi mikroflora tanah alami yang sudah ada, sehingga dapat dijadikan sumber nutrisi bagi organisme-organisme pemakan mikroflora khususnya mesofauna tanah. Kehadiran mesofauna tanah inilah yang akan membentuk pori-pori pada dinding lubang resapan dan sekitar, sehingga dapat meningkatkan kapasitas penyerapan air / infiltrasi.

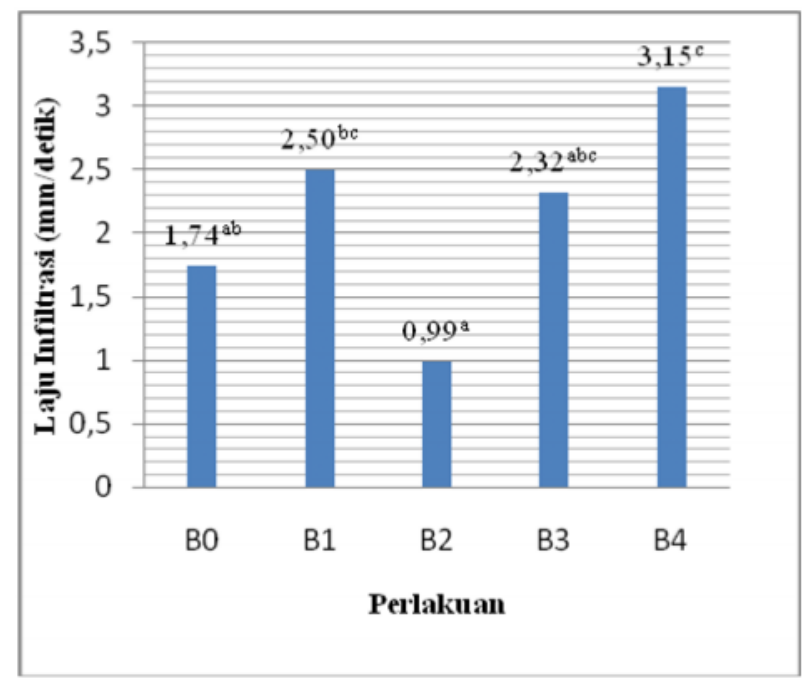

Gambar 7. Laju Infiltrasi 30 hari. B0, Kontrol; B1, EM4; B2, Bioklin; B3, Mig Dec; B4, Orgadec

Berdasarkan analisis statistik yang dilakukan pada setiap perlakuan lubang resapan setelah 30 hari, hanya perlakuan biostarter Orgadec saja yang memiliki perbedaan secara nyata terhadap kontrol. Laju infiltrasi pada lubang dengan Orgadec mengalami kenaikan sebesar $81 \%$ 
dibandingkan dengan lubang tanpa perlakuan (kontrol). Hal ini sesuai dengan data kelimpahan pada Tabel 1 yang menunjukkan bahwa kelimpahan mesofauna tanah terutama untuk taksa Oribatida pada lubang perlakuan Orgadec paling tinggi diantara semua lubang perlakuan yang lain.

Secara statistik, perlakuan penambahan biostarter EM4 dan Migdec pada umur LRB 30 hari tidak berbeda nyata terhadap kontrol, meskipun secara umum mampu meningkatkan laju infiltrasi 33\% sampai dengan 44\%. Hal ini membuktikan bahwa adanya komposisi jamur pada biostarter mampu meningkatkan kelimpahan taksa yang menyukainya seperti Oribatida serta nutrisi secara keseluruhan mampu keadaan fisik dan kimia tanah.

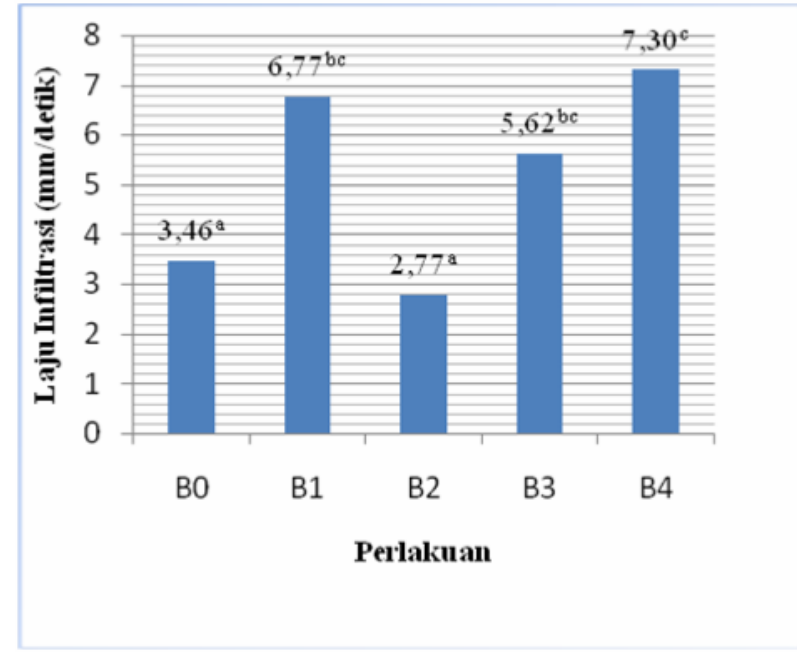

Gambar 8. Laju Infiltrasi 50 hari. B0, Kontrol; B1, EM4; B2, Bioklin; B3, Mig Dec; B4, Orgadec

Perbandingan laju infiltrasi pada setiap perlakuan di umur lubang 50 hari mengalami kesamaan pola dengan umur lubang 30 hari. Berdasarkan analisis statistik, lubang dengan perlakuan EM4, Migdec dan Orgadec memiliki beda nyata terhadap kontrol. Hal ini berarti penambahan biostarter EM4, Migdec dan Orgadec pada masing-masing lubang memiliki pengaruh positif pada laju infiltrasi lubang resapan dibandingkan dengan lubang tanpa biostarter (kontrol).
Perlakuan penambahan EM4, Mig Dec dan Orgadec pada LRB mampu meningkatkan laju infiltrasi $62 \%$ - 111\% dibandingkan dengan lubang tanpa perlakuan (kontrol). Hal ini sesuai dengan Tabel 4.2, kelimpahan individu terutama taksa Oribatida pada lubang dengan EM4, Mig Dec dan Orgadec lebih tinggi di umur 50 hari. Laju infiltrasi pada perlakuan Bioklin lebih rendah dibandingkan dengan kontrol baik pada umur LRB 30 hari maupun 50 hari. Hal ini sesuai dengan kelimpahan total mesofauna yang ditemukan di LRB baik pada umur 30 hari maupun 50 hari lebih rendah dibandingkan dengan kontrol. Faktor yang memengaruhi hal tersebut mungkin dikarenakan mesofauna tanah khususnya taksa-taksa yang lebih berperan dalam pembentukan biopori kurang menyukai komposisi mikroorganisme pada Bioklin sebagai nutrisi.

3. Korelasi Struktur Komunitas Mesofauna Tanah dengan Kapasitas Infiltrasi

Tabel 5 Korelasi $\left(r_{s}\right)$ antara Jumlah Individu, Jumlah Oribatida, Jumlah Mesostigmata dan Keanekaragaman dengan Infiltrasi

\begin{tabular}{lcl}
\hline & \multicolumn{2}{c}{ Infiltrasi } \\
\cline { 2 - 3 } & 30 hari & 50 hari \\
\hline Jumlah Individu & 0,70 & $1,00^{* * *}$ \\
Jumlah Oribatida & $0,90^{*}$ & $0,90^{*}$ \\
Jumlah Mesostigmata & 0,40 & 0,40 \\
Keanekaragaman & $-0,90^{*}$ & 0,40 \\
\hline$* \quad$ Korelasi signifikan pada tingkat 5\% \\
$* * \quad$ Korelasi signifikan pada tingkat 1\%
\end{tabular}

Variabel jumlah Oribatida berkorelasi kuat dengan infiltrasi dengan koefisien yang mendekati 1. Hal itu berarti peningkatan jumlah Oribatida setelah diberi perlakuan mampu meningkatkan laju infiltrasi pada lubang resapan. Oribatida dan Mesostigmata dipilih sebagai variabel korelasi karena kedua taksa tersebut merupakan taksa dominan dari mesofauna tanah yang ditemukan di lubang resapan. Adapun koefisien korelasi pada keanekaragaman pada LRB umur 30 hari cukup tinggi, tetapi bernilai negatif. Hal itu menunjukkan bahwa keanekaragaman mesofauna tanah berkorelasi dengan infiltrasi, tetapi hubungan 
kedua variabel berbanding terbalik, yang artinya bahwa hanya jenis-jenis taksa tertentu saja yang sangat berpengaruh terhadap infiltrasi air. Hal ini dibuktikan dengan penelitian yang dilakukan Leonard et al. (2004), yaitu pengaruh beberapa jenis fauna tanah seperti cacing tanah dan rayap dalam membentuk makropori sehingga dapat meningkatkan daya infiltrasi air.

\section{KESIMPULAN}

1. Penambahan biostarter pada LRB mampu memengaruhi struktur komunitas mesofauna tanah, khususnya berpengaruh positif terhadap kelimpahan terutama Oribatida dan Mesostigmata yang menyukai jenis nutrient pada biostarter

2. Produk biostarter pengurai bahan organik terutama Orgadec mampu bekerja lebih cepat dalam meningkatkan laju infiltrasi baik pada LRB umur 30 hari maupun 50 hari, sedangkan produk biostarter pengurai bahan organik lain yaitu EM4 dan Mig Dec mulai meningkatkan laju infiltrasi pada umur LRB 50 hari, dan untuk Bioklin cenderung menurunkan kelimpahan mesofauna tanah.

\section{DAFTAR PUSTAKA}

Brady, N.C., and R.R. Weil. 1999. The Nature and Property of Solis 12th ed. Prentice Hall Inc. Upper Saddle River, NJ.

Brussaard, L., M.M, Pulleman., A. Mando., and J. Six. 2006. Soil Fauna and Soil Function in The Fabric of The Food Web. Pedobiologia (50) : 447-462

Coyne, M. S. 1960. Soil Microbiology : an Exploratory Approach. Delmar Publisher United State of America.

Darmawidjaya, M. 1990. Klasifikasi Tanah. Gajah Mada University Press. Yogyakarta

Hadisuwito, S. 2007. Pupuk Kompos Cair. Agromedia Pustaka. Jakarta

Hanafiah, K. 2005. Dasar-dasar Ilmu Tanah. Grapindo. Jakarta

Hopkin, S.P. 2002. Collembola. Marcel Dekker Inc in Rahadian, R. 2009. Structure of Collembola Communityand Its Nutrient
Mineralizationas affected by application of Different Organic Manures and Effective Microorganisms. University of The Philippines Los Banos

Leonard, J., E. Perriee., and J.L. Rajot. 2004. Biological Macropores Effect on Runoff and Infiltration: a Combined Experimental and Modelling Approach. Agriculture, Ecosystems and Environment (104) : 277285

Magurran, A. E. 1988. Ecological Diversity and Its Measurement. Chapman and Hill, London

Odum, E. P.. 1993. Dasar-dasar Ekologi. (Terjemahan: T. Samingan). Gadjah Mada University Press. Yogyakarta

Scheu, S and M. Folger. 2004. Single and Mixed Diets in Collembola : Effect on Reproduction and Stable Isotope Fractionation. Functional Ecology (18): 94102

Schneider, K. 2005. Feeding Biology and Diversity of Oribatids Mites. Darmstadt University.

Sutanto, R. 2002. Penerapan Pertanian Organik. Kanisius. Yogyakarta

Swift, M.J., O.W. Heal., and J.M. Anderson. 1979. Decomposition in Terrestrial Ecosystem. University of California Press. Barkeley in Rahadian, R. 2009. Structure of Collembola Communityand Its Nutrient Mineralizationas affected by application of Different Organic Manures and Effective Microorganisms. University of The Philippines Los Banos

Wallwork, J A. 1970. Ecology of Soil Animal. McGraw-Hill Publishing Company Limited. England

Wuest, S. B. 2001. Soil Biopore Estimation : Effect of Tillage, Nitrogen and Photographic Resolution. Soil and Tillage Research Journal (62) : 111-116

Yulipriyanto, H. 2010. Biologi Tanah dan Strategi Pengelolaannya. Graha Ilmu. Yogyakarta 
BIOMA, Desember 2013

Vol. 15, No. 2, Hal. 81-89

ISSN: 1410-8801 